\title{
BRIBERY AND GRATUITY: REGULATORY ANALYSIS AND JUDICIAL RESPONSE
}

\author{
Ach. Tahir ${ }^{1}$, Mahrus Ali ${ }^{2}$, Muhammad Arif Setiawan ${ }^{3}$ \\ ${ }^{1}$ Faculty of Syariah and Law, State Islamic University of Sunan Kalijaga, Yogyakarta \\ ${ }^{2,3}$ Faculty of Law, Universitas Islam Indonesia, Yogyakarta \\ mahrus_ali@uii.ac.id
}

\begin{abstract}
This paper is aimed at analyzing the concepts and parameters to determine an act as a bribery and gratuity in the Anti-Corruption Law and court cases. This involved the application of the doctrinal legal research to understand these differences. The results of this study showed that bribery requires a meeting of mind between the bribe givers and bribe recipients which is not found in gratuity. The reporting mechanism and the reversal burden of proof do not apply to bribery while Operation Catching Hand does not apply to gratuity due to its inability to satisfy the provisions of the Criminal Procedure Code. Criminal sanctions are also imposed on both the giver and the recipient of a bribe while the act of a giver in gratuity is not considered as a criminal offense. The study also found that the court failed to apply these essential differences.

Keywords: Caught Hand; Meeting Of Mind; Report Mechanism
\end{abstract}

\section{INTRODUCTION}

\section{A. Background}

Anti-Corruption Law of Indonesia regulates 7 types of criminal acts of corruption including those associated with state financial losses, embezzlement in office, bribery, extortion, conflicts of interest in procurement, fraud, and gratification. In comparison with the others, the formulation of bribery offenses in the Law is at most regulated in Articles 5, 6, 11, $12 \mathrm{a}, \mathrm{b}, \mathrm{c}$, and $\mathrm{d}$ as well as Article 13. Moreover, the data released by the Corruption Eradication Commission (KPK) between 2014-2019 shows that $65 \%$ of corruption cases in Indonesia are bribery. ${ }^{1}$ The Catching Hand (OTT) conducted by the KPK from 2016-2019 totaling 87 times was also all related to bribery. ${ }^{2}$ Unfortunately, this Law does not provide a specific meaning or clear parameters related to the act of bribery despite its frequent occurrence and regulation in several offenses. This, therefore, affects the handling of bribery cases both by the KPK, the police, the prosecutor's office, and the court. ${ }^{3}$ It also shifts the establishment of a legal

1 Komisi Pemberantasan Korupsi, “KPK Annual Report 2018” (Jakarta, 2018), https://www.kpk.go.id/ images/Integrito/LaporanTahunanKPK/Laporan-Tahunan-KPK-2018-BahasaInggris-Website.pdf.

2 Komisi Pemberantasan Korupsi, “KPK Annual Report 2019” (Jakarta, 2019), https://www.kpk.go.id/ images/pdf/Laporan-Tahunan-KPK-2019-Bahasa.pdf.

3 Adalgiza A. Nùñez, "International Business, Bribery, and Criminal Liability," New Jersey Lawyer, (2014), 65. 
norm from the legislators to law enforcement by providing them the power to declare an action as a bribery. ${ }^{4}$

Previous research on bribery has actually been done, but the study mainly emphasized on one aspect of offense of bribery. Budiman (2020) stressed application of a legal provision of bribery in Anti-Corruption Law to certain corruption case. ${ }^{5}$ Golonggom, Manopo and Attie (2021) only focused on the criminal sanctions for perpetrators of the crime of bribery and strategies to overcome such offense, ${ }^{6}$ while Remoeo and Haspada limited the research on applying criminal sanctions of both active and passive bribery for state officials. ${ }^{7}$ None of these studies have elaborated the characteristics of offenses of bribery promulgated in the Anti-Corruption Law. On the offense of receiving gratuity, previous study also focused on the mechanism for reporting and proving the criminal act of gratuity as conducted by Rusadi, Sukinta and Baskoro (2019). ${ }^{8}$ In addition, Iskandar and Kurniawan (2020) conducted research on the factors affecting the occurrence of gratuity, ${ }^{9}$ while Bethesda (2019) focused on the public's perception of receiving gratuity. ${ }^{10}$

These studies missed and ignored the important nature of an offense of accepting gratuity and its difference from bribery. The court decisions concerning the cases of bribery and receiving gratuity was also not found in those research. In this sense, this study was conducted to provide a comprehensive understanding of bribery and gratification offenses. This paper aims to analyze the differences between an act of bribery and gratuity in both Anti-Corruption Law and court cases.

4 William J. Stuntz, "The Pathological Politics of Criminal Law," Michigan Law Review 100, no. 3 (2001): 505-598, https://doi.org/10.2307/1290411.

5 Maman Budiman, "Penerapan Pasal 5 Ayat (1) Huruf b Undang-Undang Pemberantasan Tindak Pidana Korupsi," Jurnal Yudisial 13, no. 1 (September 7, 2020): 73, https://doi.org/10.29123/JY.V13I1.391.

6 Mohamad N. Golonggom, Berlian Manopo, and Attie Olii, "Penegakan Tindak Pidana Suap Menurut Ketentuan Hukum Pidana Nasional," Lex Crimen 10, no. 5 (April 7, 2021): 128-129, https://ejournal.unsrat.ac.id/index.php/lexcrimen/article/view/33430.

7 Anto Romeo and Deny Haspada, "Penerapan Sanksi Pidana Suap Aktif dan Suap Pasif Bagi Pejabat Negara Berdasarkan Undang-Undang Nomor 20 Tahun 2001 Tentang Perubahan Atas UndangUndang Nomor 31 Tahun 1999 Tentang Pemberantasan Tindak Pidana Korupsi," Iustitia Omnibus (Jurnal Ilmu Hukum) 2, no. 1 (June 11, 2021): 11, http://journal.unla.ac.id/index.php/iustitia/article/view/1745.

${ }^{8}$ Fry Anditya R. P. Rusadi, Sukinta, and Bambang D. Baskoro, "Penetapan Gratifikasi Sebagai Tindak Pidana Korupsi dan Pembuktiannya dalam Proses Peradilan Pidana," Diponegoro Law Journal 8, no. 2 (2019): 1163-1164, https://ejournal3.undip.ac.id/index.php/dlr/article/view/25460/22729.

9 Irvan S. Iskandar and Teguh Kurniawan, "Gratifikasi Di Badan Usaha Milik Negara Berdasarkan Motif Kecurangan: Sebuah Tinjauan Literatur,” JIIP: Jurnal Ilmiah Ilmu Pemerintahan 5, no. 2 (2020): 81-97, https://doi.org/10.14710/jiip.v5i2.7690.

10 Elisabeth Bethesda, "Masyarakat Memandang Gratifikasi Dalam Tindak Pidana Korupsi," Jurnal Komunikasi Hukum 5, no. 2 (November 17, 2019): 73-74, https://doi.org/10.23887/JKH.V5I2.18311. 


\section{B. Problems}

This paper elaborates two important legal issues, namely the distinctive natures between bribery and gratuity in Anti-Corruption Law and judicial response to these differences.

\section{Methods}

This paper is a doctrinal legal research that mainly relies on statues and court cases of bribery and gratuity as its primary sources of information. It is supported by opinions by legal scholars as a secondary data to justify the analysis on the assumption that the essential natures and parameters between bribery and gratuity as defined by scholars need to be clearly distinguished. The data collection is through literature study and legal document of court decision. This paper also uses an analytical descriptive approach to examine relevant provisions from status and to analysis some court cases regarding the bribery and gratuity through data reduction, presentation and conclusion.

\section{RESULT AND DISCUSSION}

\section{Legal Provision of Bribery}

Bribery is generally defined as 'the abuse of public office for private gain'. ${ }^{11}$ It specifically means giving or promising a state administrator or public servant some certain privileges. ${ }^{12}$ Due to the favor obtainable from the position ${ }^{13}$ and has also been equated with the positional offense. ${ }^{14}$ This study was, however, limited to public positions without the inclusion of the private sector ${ }^{15}$ due to the fact that the Anti-Corruption Law does not include bribery in the private sector as a corruption criminal actin line with the 2003 United Nations Convention against Corruption ratified by Indonesia with Law Number 7 of 2006. ${ }^{16}$

11 David M. Fuhr, "Of Thieves and Repressors: The Interplay Between Corruption and Human Rights Violations," 5 Elon L. Rev. 271 5, no. 271 (2013): 1-29, https://heinonline.org/HOL/Page?handle=hein. journals/elonlr5\&id=279\&div=\&collection=.

12 Eric C. Chaffee, "From Legalized Business Ethics to International Trade Regulation: The Role of the Foreign Corrupt Practices Act and Other Transnational Anti-Bribery Regulations in Fighting Corruption in International Trade.," Mercer Law Review 1 (2016), https://heinonline.org/HOL/Page?handle=hein.journals /mercer65\&id=727\&div=\&collection=.

${ }^{13}$ Lawrence J. Trautman and Altenbaumer-Price Kara, "Lawyers, Guns and Money - the Bribery Problem and U.K. Bribery Act 2010," SSRN Electronic Journal 47 (2013), https://doi.org/10.2139/ssrn.2276738.

${ }^{14}$ Marsha Z. Gerber and Elane L. Lawson, "Business Entertainment 'Texas Style' Here and Abroad What You Need to Know," Texas Bar Journal, (2012), 536.

${ }^{15}$ Léonce Ndikumana, "The Private Sector as Culprit and Victim of Corruption in Africa.," PERI Working Paper, (2013), 46.

${ }^{16}$ Fariz Cahyana, "Urgensi Pengaturan Suap di Sektor Swasta Sebagai Tindak Pidana Korupsi di Indonesia," Jurist-Diction 3, no. 1 (January 29, 2020): 61, https://doi.org/10.20473/jd.v3i1.17623. 
The offenses of bribery in the Anti-Corruption Law is characterized by several natures. There must be meeting of mind between the bribe giver and recipient. This means that bribe is not established except the two parties have the will and are aware of the action. From economics view, it requires the activities of supply and demand between them. ${ }^{17}$ In addition, the bribery case necessitates the use of Article 55 paragraph (1) $1^{\text {st }}$ of Criminal Code specifically concerning participation to crime (medeplegen) that requires double intention; intentional cooperation to commit an offense and performance of an offense together committed internationally. ${ }^{18}$ Therefore, it is not appropriate to convict only the giver or recipient of a bribe. For example, in the Century Bank scandalous corruption case, the panel of judges convicted Budi Mulia, a former Governor of Central Bank of Indonesia, for participating in the act in a quo case based on Article 55 paragraph (1) $1^{\text {st }}$ of Criminal Code while Boediono, a former Vice President of Indonesia and the senior Governor at the time, was not suspected or even convicted even though the verdict proves that the century bailout decision can only be taken collectively and collegially. ${ }^{19}$

The evil intention to commit a prohibited act usually occurs before a bribe offense is committed through the use of an object such as a gift or promise. ${ }^{20}$ This study, however, argued that it is inappropriate to describe a gift as a bribery object due to the fact that it is allowed but proposed the use of the term 'something' instead which is further defined as anything of economic value. It is not necessary that the recipient has the bribery object in possession before a case is established as long as such an individual has sufficient control over the item. Promises are not in the form of goods but are generally related to actions of the giver in response to an activity conducted by the recipient. The bribe giver can be anyone including individuals, corporations, public servants, advocates, judges, or even state administrators while the recipients are limited to civil servants, state administrators, advocates, and judges. ${ }^{21}$ This is important

\footnotetext{
17 Lindsay Arrieta, "Attacking Bribery At Its Core: Shifting Focus To the Demand Side of the Bribery Equation," Public Contract Law Journal 45, no. 4 (2016): 587-612, https://heinonline.org/HOL/Page? handle=hein.journals/pubclj45\&id=614\&div=\&collection=.

18 Jan Remmelink, Hukum Pidana (Jakarta: PT. Gramedia Pustaka Utama, 2003); Eddy O.S. Hiariej, Prinsip-Prinsip Hukum Pidana, Cet. Pertama (Yogayakarta: Cahaya Atma Pustaka, 2016).

19 Yeni Sri Lestari, "Kartel Politik Dan Korupsi Politik Di Indonesia," Pandecta : Jurnal Penelitian Ilmu Hukum (Research Law Journal) 12, no. 1 (June 2, 2017): 67-75, https://doi.org/10.15294/PANDECTA.V12I1.7820; Ridwan, Diskresi dan Tanggung Jawab Pemerintahan (Yogayakarta: FH UII Press, 2014).

${ }^{20}$ Ninus D. Andarnuswari (ed), "Kajian Implementasi Pasal Gratifikasi dalam Putusan Pengadilan (Edisi Revisi)," 2019, 51, https://aclc.kpk.go.id/wp-content/uploads/2020/04/Buku-Kajian-ImplementasiPasal-Gratifikasi-KPK2019-LowRes-08052020.pdf.

${ }^{21}$ Elizabeth K. Spahn, "Implementing Global Anti-Bribery Norms: From the Foreign Corrupt Practices Act to the OECD Anti-Bribery Convention to the U.N. Convention Against Corruption," Indiana International \& Comparative Law Review 23, no. 1 (2013): 1-34, https://doi.org/10.18060/17871.
} 
considering the fact that bribe is related to the position of the recipient which is usually public as observed with public servants or state administrators not doing anything in their position or found using their authority or position to conduct some activities. ${ }^{22}$

The prohibited acts committed by the bribe giver include 'giving or promising something to the public servants or state administrators' (Article 5 paragraph 1 letter a), 'giving something to civil servants or state administrators' (Article 5 paragraph 1 letter b), 'giving or promising something to an advocate' (Article 6 paragraph 1 letter a), 'giving or promising something to a judge' (Article 6 paragraph 1 letter b)', and 'giving gifts or promises to civil servants keeping in mind the power or authority attached to the position or his position' (Article 13). Meanwhile, the prohibited conduct for the recipients is 'accepting gifts or promises' (Article 5 paragraph 2), 'judges or advocates accepting gifts or promises' (Article 6 paragraph 2), 'public servants or state administrators receiving gifts or promises despite knowing they are provided in order to influence their decisions or actions is contrary to their obligations' (Article 12 letter a), 'public servants or state administrators receiving gifts even though they reasonably suspect the gifts are meant to influence their professional conduct is contrary to their obligations' (Article 12 letter b), 'the judge receiving a gift or promise' (Article 12 letter c), and 'the advocate receiving a gift or promise' (Article 12 letter d). Article 12 letter a focuses on the bribe provided to the civil servants or state administrators to conduct a certain act while letter b emphasizes those provided after the action has been conducted.

The reversal burden of proof does not apply in bribery cases. Neither the bribe giver nor the recipient is obliged to prove that the gift or promise has nothing to do with the public position of the recipient since it is the responsibility of the public prosecutor. ${ }^{23}$ However, it is possible to have catch hands/caught operations (OTT) in bribes offenses as observed in KPK where they are implemented in several corruption cases which are almost impossible to solve using conventional methods. ${ }^{24}$ Even though it is possible to have OTT in bribery

\footnotetext{
${ }^{22}$ Mahrus Ali and Deni Setya Bagus Yuherawan, Delik-delik Korupsi (Jakarta: Sinar Grafika, 2021).

${ }^{23}$ Muh. Arief Syahroni, M. Alpian, and Syofyan Hadi, "Pembalikan Beban Pembuktian dalam Tindak Pidana Korupsi," DiH: Jurnal Ilmu Hukum 15, no. 2 (July 11, 2019): 124-133, https://doi.org/10.30996/ dih.v15i2.2478; Wahyu Wiriadinata, "Korupsi dan Pembalikan Beban Pembuktian," Jurnal Hukum \& Pembangunan 43, no. 1 (2017): 117, https://doi.org/10.21143/jhp.vol43.no1.1508; Mulyanto, "Praktik Pembatasan Pembalikan Beban Pembuktian dalam Pengadilan Tipikor (Studi Pada Perkara Korupsi RAPBD Kota Semarang di Pengadilan Tipikor Kota Semarang)," Jurnal Jurisprudence 6, no. 2 (2017): 116, https://doi.org/10.23917/jurisprudence.v6i2.3009.

${ }^{24}$ Lucinda A. Low, Sarah R. Lamoree, and John London, "The 'Demand Side' of Transnational Bribery and Corruption: Why Leveling the Playing Field on the Supply Side Isn't Enough," in Fordham
} 
offenses, those conducted by KPK do not actually violate the four criteria of being caught red-handed as shown in Article 1 number 19 of Law Number 8 of 1981 concerning the Criminal Procedure Code (KUHAP). The criteria includes arresting a person, while committing a crime, immediately after the crime is committed, based on the confirmation of the general public, and the moment an object allegedly used in committing a crime indicates the perpetrator participated or assisted in the process. ${ }^{25}$

In a case of bribery offense, OTT is in the form of a promise to a civil servant to receive favor based on the position of such an individual contrary to obligations. ${ }^{26}$ For example, a defendant promises a judge a sum of IDR 2 billion to acquit such person in a corruption case, bribery is established when there is an agreement between them. It is important to argue that the offense is completed on the day where the agreement was made. Assuming March 30, 2020, even though the promise was fulfilled on July 23, 2020, after the defendant has been acquitted by the judge, and KPK implemented OTT against both the defendant and the judge. The four criteria of being caught red-handed in Article 1 number 19 of the Criminal Procedure Code have not been met, therefore, the process is declared as illegal OTT due to the existence of 4 months between the period the offense was committed and OTT was implemented by KPK.

\section{Gratuity vs Bribery}

Gratuity is determined to be an offense in Article 12B of the AntiCorruption Law formulated to include the following:

1. Every gratuity to a civil servant or a state administrator is considered a bribe as long as it relates to the position and contrary to the obligations or duties of such individual with the following conditions: a) In the amount of IDR $10,000,000.00$ (ten million rupiahs) or more with proofs the gratuity is not a bribe made according to the recipient; b) The value less than IDR $10,000,000.00$ (ten million rupiahs) with proofs the bribery is conducted by the public prosecutor.

2. Criminal punishment for civil servants or state administrators as referred to in paragraph (1) is life imprisonment or imprisonment for a minimum of 4 (four) years and a maximum of 20 (twenty) years, and a minimum fine of IDR 200,000,000.00 (two hundred million rupiahs) and a maximum of IDR $1,000,000,000.00$ (one billion rupiahs).

\footnotetext{
Law Review, $\quad$ vol. $\quad$ 84, $\quad 2015, \quad$ 563-599, https://heinonline.org/HOL/Page?handle=hein.journals/flr84\&id=581\&div = \& collection=.

25 Rizky Oktavianto and Norin M. R. Abheseka, "Evaluasi Operasi Tangkap Tangan KPK," Integritas: Jurnal Antikorupsi 5, no. 2 (December 30, 2019): 117-131, https://doi.org/10.32697/INTEGRITAS. V5I2.473.

26 Adami Chazawi, Hukum Pidana Korupsi di Indonesia (Jakarta: Rajawali Press, 2016).
} 
This article defines 'gratuity' as a gift in the broadest sense including the provision of money, goods, rebates (discounts), commissions, loans without interest, travel tickets, lodging facilities, tourist trips, free medical treatment, and other facilities which are received both domestically and abroad or conducted using electronic or non-electronic means. The acceptance of gratuities by civil servants or state administrators by virtue of their position and against their obligations or duties is known as gratification. There is usually no meeting of mind between the gratuity giver and the public servants or state administrators as the recipients. The existence of a meeting of mind makes the gift a bribe with the gratuity objects broadly as previously explained in Article 12B paragraph (1).

The gratuity recipient is obliged to prove that the gift received is not a bribe and has nothing to do with the position not contrary to the obligation if the value is IDR. 10,000,000 or more. Such cases also involve provisions or mechanisms of reporting as confirmed by Article 12C paragraph (1), (2), and (3) that the offense in Article 12B paragraph (1) does not apply if the recipient reports the gratuity received to the KPK no later than 30 (thirty) working days from the date where the gratuity is received to determine the gratuity belong to the recipient or the state.

The provision of Article 12C eliminates criminal prosecution against civil servants or State administrators receiving gratuities. This study asserts that acceptance of gratuity itself is an offense but the prosecution process depends on whether or not a report has been filed by the recipient to the KPK no later than 30 working days from the date it was received after which the commission determines either the gratuity belongs to the recipient or the state. Even though the Anti-Corruption Law interprets gratuity broadly, it does not include sexual relations services provided by a person to a public servant or state administrator known as sexual gratuity due to its ability to cause problems as well as the impracticality of determining either the action belongs to the recipient or state. Does the inclusion of sexual service in the meaning or form of gratuity makes KPK confiscate 'women's goods' as the property of the State and then auction it off? This is, of course, impossible and causes women dignity. Therefore, gratuity needs to be limited to the material forms and types.

Another nature of gratuity is the emergence of evil intention precisely after civil servants or state administrators receive a gift because of their position. ${ }^{27}$ They are, however, allowed to report such gist within a 30-day work period to avoid being prosecuted based on Catching Hands Operation (OTT). KPK is not

27 Nur Mauliddar, Mohd Din, and Yanis Rinaldi, "Gratifikasi sebagai Tindak Pidana Korupsi Terkait Adanya Laporan Penerima Gratifikasi," Kanun Jurnal Ilmu Hukum 19, no. 1 (2017): 155-173, http://www.jurnal.unsyiah.ac.id/kanun. 
authorized to conduct OTT on corruption cases related to the acceptance of gratuities due to the fact that the four criteria of being caught red-handed previously described are not satisfied. For example, a civil servant receives gratuity between $3^{\text {rd }}$ and $4^{\text {th }}$ August of 2021. Thirty working days later, the Corruption Eradication Commission is not authorized to conduct OTT due to the provision of Article 12C paragraph (1) and 12B paragraph (1) Anti-Corruption Law which prohibit the KPK to conduct OTT after 30 working days of receiving gratuities because it contradicts the criteria previously explained. To understand more clearly, the following table shows the distinctive natures between bribery and gratuity:

Table 1. Gratuity vs Bribery.

\begin{tabular}{|c|c|c|}
\hline Elements & Gratuity & Bribery \\
\hline Perpetrator & $\begin{array}{c}\text { Civil servant/state } \\
\text { official }\end{array}$ & $\begin{array}{c}\text { Civil servant/state } \\
\text { official/lawyer/j } \\
\text { udge/corporation } \\
\text { /individual }\end{array}$ \\
\hline Meeting of mind & No & Yes \\
\hline $\begin{array}{l}\text { Intention to commit an } \\
\text { offense }\end{array}$ & $\begin{array}{c}\text { After receiving } \\
\text { gratuity }\end{array}$ & $\begin{array}{c}\text { Before a bribe } \\
\text { occurs }\end{array}$ \\
\hline $\begin{array}{l}\text { Reversal burden of } \\
\text { proof }\end{array}$ & Applicable & Non-applicable \\
\hline Reporting mechanism & Applicable & Non-applicable \\
\hline OTT & Impossible & Possible \\
\hline
\end{tabular}

Source: data processed by the authors

The table above can be used as a practical guide or checklist for anyone, especially law enforcement officer, to find out the difference between offense of bribery and offense of receiving gratuity. The Corruption Eradication Commission (KPK) cannot carry out a Hand Catching Operation on someone who is strongly suspected of receiving gratuities. Provisions regarding the reporting mechanism do not apply to bribery offenses, but are limited only to offenses of accepting gratuity.

\section{Judicial Response}

In the bribery case of Ridwan Mukti, former Governor of Bengkulu Province, the court found guilty of the crime committed joinlty with Lily Martinai Maddari and Rico Diansari (Director of Rico Putra Selatan, Ltd) for violating Article 12 a of AntiCorruption Law and Article 55 paragraph (1) 1st of the Criminal Code. The convict was proven guilty to have received cash as IDR 1.000.000.000 from Jhoni Wijaya as the representative of Statika Mitrasarana, Ltd through Rico Diansari eventhough it is known or reasonably suspected that the gift was given in order not to annul the project 
won by Statika Mitrasarana, Ltd. In the trial, it was proven that the money was not received directly by the defendant, but by defendant's wife through Rico Diansari.

To prove the element of 'receiving gifts or promise', the court considered that based on the legal fact, what Lily Martiani Maddari did was under the knowledge of Ridwan Mukti. In addition, the purpose of this gifts was as a sign of gratitude because Statika Mitrasarana, Ltd has won a road improvment project from the Public Work Office of the Bengkulu Provincial Government in 2017.8 ${ }^{28}$ This study argued that the court missed the use of Article 12 in this case since the offense is directed against giving gifts or promise to influence public servant or state administrator. The fact that Statika Mitrasarana, Ltd won the project because it has met the necessary requirments and the defendant has not any role in the decision. In addition, the project has been declared completely by the employer long before the amount of IDR 1.000.000.000 was given by Jhony Wijaya to Lily Martiani Maddari through Rico Diansari. In the indictment, the primary purpose of giving the money is to prevent the defendant annul the project won by Statika Mitrasarana, Ltd. This fact was contrary to the court's legal consideration. The involvement of the defendant in receiving bribery was poorly proven either though witness testimony or tapping as an electronic evidence. The court concluded that the defendant has proven guilty of recieving that money just because he is the husband of Lily Martiani Maddari without any legal evidence. ${ }^{29}$

It was also strictly stated in the court's legal consideration as follow:

Hearing the statement of the defendant with the rising intonation of his voice, it is a natural thing that can be experienced by anyone in general and can result in worries from partners who have won the project including Jhoni Wijaya. If you do not submit the commitment money, it is feared that there will be instructions from the defendant as Governor to employees at the Bengkulu Provincial Government PUPR Service, which can hinder project implementation and can make it difficult to get the next project in Bengkulu Province or at least the project that has been won by the company will be blacklisted by the defendant (Indonesia vs Ridwan Mukti 2017)

The legal consideration were missing because it lead to prove the extortion offense in Article 12 letter e, especially the element of coercion either by force or threats of violence. ${ }^{30}$

In the gratuity case of Nur Alam, a former Governor of Southeast Sulawesi, the verdict of the first instance court, appeal, and casation stated that

\footnotetext{
28 Mahkamah Agung Republik Indonesia, Putusan Pengadilan Negeri Bengkulu Nomor: 45/Pid.Sus-TPK/2017/PN BGL (2017).

${ }^{29}$ Mahkamah Agung Republik Indonesia, Putusan Kasasi Mahkamah Agung RI Nomor: 1219 K/Pid.Sus/2018 (2018).

30 Setiadi Wicipto, "Korupsi di Indonesia Penyebab, Hambatan, Solusi dan Regulasi," Legislasi Indonesia 15, no. 3 (2018): 249-262, https://e-jurnal.peraturan.go.id/index.php/jli/article/view/234.
} 
Nur Alam was proven to have received a gratuity considered a bribe from Richcorp International Ltd in the amount of IDR. 40,268,792,850 from illegal grounds and not reported to the KPK within the prescribed time limit. The decision was based on several legal considerations. The money borrowed by the defendant personally from Chen Linze certainly opened the opportunity for a conflict of interest to the defendant as the Southeast Sulawesi Governor. Besides, sending money to the defendant to buy an insurance policy at AXA Mandiri on behalf of the defendant using his biological children as beneficiaries also proves that the money is not a Chen Linze's investment to advance Southeast Sulawesi but from Richcorp International Ltd for the defendant. In addition, all cancellation/disbursement of the three AXA Mandiri insurance policies on behalf of the defendant has been accommodated in the Non-Customer Giro (GNC) account of IDR 30,481,436,261.00. At the defendant's request, the money was transferred to the account of Timbel Mas Abadi Ltd. gradually with each transaction below the nominal value of IDR 500,000,000 to avoid suspicion from PPATK. Finally, the money in the Sultra Timbel Mas Abadi Ltd. account, at the defendant's request to Bank Mandiri, was also transferred in batches with the value less than IDR 500,000,000 to avoid suspicion from PPATK with the destination account being Untung Anaugi Ltd, Gino Valentino Ltd, and Bososi Pratama Ltd. ${ }^{31}$

According to this study, the money received by the defendant was not a gratuity or a bribe and the defendant's actions are purely considered a civil law in the form of investment placements and personal loans. It is strengthened by several facts that investment Agreement No. CI/NA/IA/2010/001 of 19 August 2010 conducted by Richcorp International Ltd and the defendant in a personal capacity. Provisional Fund Provision Agreement No. PPDS/RC/NA/2010/002 dated August 19, 2010. Moreover, based on the investment agreement and personal loan in the amount of IDR 40,268,792,850, the defendant apparently returned the money to Richcorp International Ltd as observed from these two pieces of evidence. First, evidence of money transfers from Giofedi Rauf to Richcorp International Ltd totaling IDR 15,000,000,000 dated May 30, 2013, IDR 15,000,000,000 dated June 3, 2013, and IDR 10. 750.000.000 dated June 4, 2013. A letter dated June 10, 2013, from Richcorp International Ltd to Geofedi Rauf regarding evidence of receipt of money transferred by the defendant in the amount of IDR. 40,750,229,110. This shows that the defendant returned the money to Richcorp International Ltd before the legal investigation was conducted by KPK. The money was also returned in accordance with the

31 Mahkamah Agung Republik Indonesia, Putusan Pengadilan Negeri Jakarta Pusat Nomor: 123/Pid.Sus-TPK/2017/PN Jkt.Pst (2017). 
contents of Investment Agreement No. CI/NA/IA/2010/001 dated August 19, 2010, between Richcorp International Ltd and the defendant is in a personal capacity and Agreement of Temporary Funds Provision No. PPDS/RC/NA/2010/002 dated 19 August 2010. ${ }^{32}$ This, therefore, means there is no connection between the defendant's position as the Southeast Sulawesi Governor and transactions. It is important to urgue that it is only possible to establish gratuity as long as it is related to the defendant's position.

\section{CONCLUSION}

Bribery and gratuity are malversations. In bribery, the bribe giver and receiver need to agree to commit a crime before it happens and the existence of the word 'agreed' becomes the basis for the crime imposed on both of them. The Anti-Corruption Law shows the givers can be anybody from any background while the recipients are limited only to certain performers. Moreover, the OTT usually conducted by KPK are all related to bribery cases. It was also discovered that reversal burden of proof and reporting mechanism apply only to gratuities and this means that the recipients have 30 working days after gratification has been received to report to the KPK to avoid criminal prosecution. Failure to report means that the recipient is corrupt. The court failed to deeply understand the distinctive nature of bribery particularly between receiving gifts in order to influence the decisions of public servant and the gifts which are meant to influence the professional conduct of public servant. Conduncting contractual or business relation by public servant or state administrator is not deemed as gratuity as long as it is not contrary to his obligation in public position. This result of study can be used by Supreme Court, Corruption Eradication Commision, and Attorney General to issue the guidelines concerning the natures of bribery and gratuity as well as the practical prosecution and conviction of the criminal case of bribery and gratuity to prevent unjust punishment.

\section{REFERENCES}

Ali, Mahrus and Setya Bagus Yuherawan, Deni. Delik-delik Korupsi. Jakarta: Sinar Grafika, 2021.

Andarnuswari, Ninus D. (ed). "Kajian Implementasi Pasal Gratifikasi dalam Putusan Pengadilan (Edisi Revisi)," 2019, 51. https://aclc.kpk.go.id/wpcontent/uploads/2020/04/Buku-Kajian-Implementasi-Pasal-GratifikasiKPK2019-LowRes-08052020.pdf.

Arrieta, Lindsay. "Attacking Bribery At Its Core: Shifting Focus To the Demand Side of the Bribery Equation." Public Contract Law Journal 45, no. 4 (2016): https://heinonline.org/HOL/Page?handle=hein.journals/pubclj45\&id=614

32 Mahkamah Agung Republik Indonesia, Putusan Kasasi Mahkamah Agung RI Nomor: 2933 K/ Pid.Sus/2018 (2018). 
$\&$ div $=\&$ collection $=$.

Bethesda, Elisabeth. "Masyarakat Memandang Gratifikasi dalam Tindak Pidana Korupsi." Jurnal Komunikasi Hukum (JKH) 5, no. 2 (November 17, 2019): 62-75. https://doi.org/10.23887/JKH.V5I2.18311.

Budiman, Maman. "Penerapan Pasal 5 Ayat (1) Huruf b Undang-Undang Pemberantasan Tindak Pidana Korupsi." Jurnal Yudisial 13, no. 1 (September 7, 2020): 73-87. https://doi.org/10.29123/JY.V13I1.391.

Cahyana, Fariz. "Urgensi Pengaturan Suap di Sektor Swasta Sebagai Tindak Pidana Korupsi Di Indonesia." Jurist-Diction 3, no. 1 (January 29, 2020): 61. https://doi.org/10.20473/jd.v3i1.17623.

Chaffee, Eric C. "From Legalized Business Ethics to International Trade Regulation: The Role of the Foreign Corrupt Practices Act and Other Transnational Anti-Bribery Regulations in Fighting Corruption in International Trade." Mercer Law Review 1 (2016).https://heinonline.org/HOL/Page?handle=hein.journals/mercer65 $\&$ id $=727 \&$ div $=\&$ collection $=$.

Chazawi, Adami. Hukum Pidana Korupsi di Indonesia. Jakarta: Rajawali Press, 2016.

Fuhr, David M. "Of Thieves and Repressors: The Interplay Between Corruption and Human Rights Violations." 5 Elon L. Rev. 271 5, no. 271 (2013): 129.

https://heinonline.org/HOL/Page?handle=hein.journals/elonlr5\&id=279\& div $=\&$ collection $=$.

Gerber, Marsha Z., and Elane L. Lawson. "Business Entertainment 'Texas Style' Here and Abroad What You Need to Know." Texas Bar Journal, 2012, 536.

Golonggom, Mohamad N., Berlian Manopo, and Attie Olii. "Penegakan Tindak Pidana Suap Menurut Ketentuan Hukum Pidana Nasional." Lex Crimen 10, no. 5 (April 7, 2021):120-130. https://ejournal.unsrat.ac.id/index.php/lexcrimen/article/view/33430.

Hiariej, Eddy O.S. Prinsip-Prinsip Hukum Pidana. Cet. Pertama. Yogayakarta: Cahaya Atma Pustaka, 2016.

Iskandar, Irvan S., and Teguh Kurniawan. "Gratifikasi di Badan Usaha Milik Negara Berdasarkan Motif Kecurangan: Sebuah Tinjauan Literatur.” JIIP: Jurnal Ilmiah Ilmu Pemerintahan 5, no. 2 (2020): 81-97. https://doi.org/10.14710/jiip.v5i2.7690.

Komisi Pemberantasan Korupsi. "KPK Annual Report 2018.” Jakarta, 2018. https://www.kpk.go.id/images/Integrito/LaporanTahunanKPK/LaporanTahunan-KPK-2018-Bahasa-Inggris-Website.pdf.

“KPK Annual Report 2019.” Jakarta, 2019. https://www.kpk.go.id/images/pdf/ Laporan-Tahunan-KPK-2019Bahasa.pdf.

Lestari, Yeni Sri. "Kartel Politik dan Korupsi Politik di Indonesia." Pandecta : Jurnal Penelitian Ilmu Hukum (Research Law Journal) 12, no. 1 (June 2, 2017): 67-75. https://doi.org/10.15294/PANDECTA.V12I1.7820.

Low, Lucinda A., Sarah R. Lamoree, and John London. "The 'Demand Side' of 
Transnational Bribery and Corruption: Why Leveling the Playing Field on the Supply Side Isn't Enough.” In Fordham Law Review, 84:563-99, 2015.

https://heinonline.org/HOL/Page?handle=hein.journals/flr84\&id=581\&di $\mathrm{v}=\&$ collection $=$.

Mahkamah Agung Republik Indonesia. Putusan Kasasi Mahkamah Agung RI Nomor: 1219 K/Pid.Sus/2018 (2018).

—. Putusan Kasasi Mahkamah Agung RI Nomor: 2933 K/ Pid.Sus/2018 (2018).

- Putusan Pengadilan Negeri Bengkulu Nomor 45/Pid.Sus-TPK/2017/PN BGL (2017).

—. Putusan Pengadilan Negeri Jakarta Pusat Nomor: 123/Pid.SusTPK/2017/PN Jkt.Pst (2017).

Mauliddar, Nur, Mohd Din, and Yanis Rinaldi. "Gratifikasi Sebagai Tindak Pidana Korupsi Terkait Adanya Laporan Penerima Gratifikasi." Kanun Jurnal Ilmu Hukum 19, no. 1 (2017): 155-173. http://www.jurnal.unsyiah.ac.id/kanun.

Mulyanto. "Praktik Pembatasan Pembalikan Beban Pembuktian dalam Pengadilan Tipikor (Studi Pada Perkara Korupsi RAPBD Kota Semarang di Pengadilan Tipikor Kota Semarang)." Jurnal Jurisprudence 6, no. 2 (2017): 116. https://doi.org/10.23917/jurisprudence.v6i2.3009.

Ndikumana, Léonce. "The Private Sector as Culprit and Victim of Corruption in Africa." PERI Working Paper, (2013), 46.

Nùñez, Adalgiza A. "International Business, Bribery, and Criminal Liability." New Jersey Lawyer, (2014), 65.

Oktavianto, Rizky, and Norin M. R. Abheseka. "Evaluasi Operasi Tangkap Tangan KPK." Integritas: Jurnal Antikorupsi 5, no. 2 (December 30, 2019): 117-131. https://doi.org/10.32697/INTEGRITAS.V5I2.473.

Remmelink, Jan. Hukum Pidana. Jakarta: PT. Gramedia Pustaka Utama, 2003.

Ridwan. Diskresi dan Tanggung Jawab Pemerintahan. Yogayakarta: FH UII Pers, 2014.

Romeo, Anto, and Deny Haspada. "Penerapan Sanksi Pidana Suap Aktif dan Suap Pasif Bagi Pejabat Negara Berdasarkan Undang-Undang Nomor 20 Tahun 2001 Tentang Perubahan Atas Undang-Undang Nomor 31 Tahun 1999 Tentang Pemberantasan Tindak Pidana Korupsi." Iustitia Omnibus (Jurnal Ilmu Hukum) 2, no. 1 (June 11, 2021): 1-13. http://journal.unla.ac.id/index.php/iustitia/article/view/1745.

Rusadi, Fry Anditya R. P., Sukinta, and Bambang D. Baskoro. "Penetapan Gratifikasi sebagai Tindak Pidana Korupsi dan Pembuktiannya Dalam Proses Peradilan Pidana." Diponegoro Law Journal 8, no. 2 (2019): 11451165.

https://ejournal3.undip.ac.id/index.php/dlr/article/view/25460/22729.

Setiadi Wicipto. "Korupsi di Indonesia Penyebab, Hambatan, Solusi dan Regulasi." Legislasi Indonesia 15, no. 3 (2018): 249-262. https://ejurnal.peraturan.go.id/index.php/jli/article/view/234.

Spahn, Elizabeth K. "Implementing Global Anti-Bribery Norms: From the 
Foreign Corrupt Practices Act to the OECD Anti-Bribery Convention to the U.N. Convention Against Corruption." Indiana International \& Comparative Law Review 23, no. 1 (2013): 1-34. https://doi.org/10.18060/17871.

Stuntz, William J. "The Pathological Politics of Criminal Law." Michigan Law Review 100, no. 3 (2001): 505-598. https://doi.org/10.2307/1290411.

Syahroni, Muh. Arief, M. Alpian, and Syofyan Hadi. "Pembalikan Beban Pembuktian Dalam Tindak Pidana Korupsi." DiH: Jurnal Ilmu Hukum 15, no. 2 (July 11, 2019): 124-133. https://doi.org/10.30996/dih.v15i2.2478.

Trautman, Lawrence J., and Altenbaumer-Price Kara. "Lawyers, Guns and Money - the Bribery Problem and U.K. Bribery Act 2010." SSRN Electronic Journal 47 (2013). https://doi.org/10.2139/ssrn.2276738.

Wiriadinata, Wahyu. "Korupsi dan Pembalikan Beban Pembuktian." Jurnal Hukum \& Pembangunan 43, no. 1 (2017): 117. https://doi.org/10.21143/jhp.vol43.no1.1508. 